\title{
Trends in Dry Pea (Pisum sativum L.) Production
}

\author{
János Lazányi \\ University of Debrecen, Centre of Agricultural Sciences, \\ Institute of Agricultural Economics and Rural Development, \\ Department of Rural Development and Resource Management, \\ Debrecen
}

\section{SUMMARY}

Dry pea is an important, cool-season grain legume, which is grown worldwide on over 6 million hectares. The major producing countries outside Europe are China and Canada, followed by India, Australia, and the United States. France, Canada and Australia produce over 2 million hectares and are major exporters of peas. During the 1980's, in developed countries of the European Union, pea production rose yearly by 6-10\%, which represents a significant increase in both area and yield. Europe accounts for $50-75 \%$ of world pea production. In the 1990's, the European Union produced 4-5 million tonnes of dry pea, of which 3-4 million tonnes were used for feed and 1 million tonnes for export. At the end of the $20^{\text {th }}$ century, the growth in production was low, mainly because of the absence of support measures, and the better returns offered by other crops. In the countries of the former Soviet Union, dry pea was primarily used as feed and pea production dropped, due to a trend in livestock raising.

Food consumption of dry pea is concentrated in developing countries, where grain legumes represent a useful complement to cereal-based diets as a relatively inexpensive source of high quality protein. As a result, human consumption of grain legumes fell from 2,2 kg/capita in 1961 to $0,5 \mathrm{~kg} /$ capita in 1999. The importance of grain legumes in food protein supply decreased, while that of cereal products increased. Shortage of grain legumes has adverse effects on the nutritional standard of poor people in developing countries.

World dry pea production reached 16,7 million tonnes in 1990, with 3,7 million tonnes used as food, 11,4 million tonnes used as feed, and 1,0 million tonnes used as seed. Dry pea production was 10,9 million tonnes in 1999, and 3,5, 5,8 and 0,8 million tonnes was used as food, feed and seed, respectively. In the coming decades, world grain legume production and utilization as feed are expected to expand at a slower rate than in the 1980's. Most of the increase is expected to occur in Eastern European countries, Canada and Australia, where production is anticipated to grow at $2 \%$ annually. The projection for the new millennium was derived from adjusted trends in area and yield over the period 1961-2000, based on FAO statistical data.

\section{INTRODUCTION}

Dry pea is primarily used for human consumption and livestock feed. Dry pea contains approximately 21-25 percent protein and high levels of carbohydrates. Being a grain legume, it has high levels of amino acids, lysine and tryptophan, which are relatively low in cereals. It is low in fiber and contains $86-87 \%$ total digestible nutrients, which makes it an excellent livestock feed. Dry pea is often cracked or ground and added to cereal grain feed as it contains less trypsin inhibitors than soybean. This allows pea to be directly fed to livestock without having to go through the extrusion heating process. Research has shown that pea is an excellent source of protein supplement in swine, cow, feeder calf, dairy and poultry feed (Yacentiuk, 2001). Dry pea also may be grown as a green manure or green fallow crop. Use of field pea for green fallow protects the soil from erosion, improves soil quality, substitutes water loss by evaporation or leaching from black fallow with transpiration through plant growth, and exploits rotational benefits. Costs of tillage in black fallow are also substituted with costs of pea establishment and termination in green fallow (Lazányi, 1998, 2002).

Flowering usually begins 40 to 50 days after planting. Flowering is normally two to four weeks, depending on the flowering habit and weather during flowering. Indeterminate flowering varieties will flower for long periods and ripening can be prolonged into drought under Hungarian conditions (Kurnik, 1970; Iszályné and Lazányi, 1993; Iszályné, 2002). Indeterminate varieties reach maturity later, ranging from 90 to 100 days. Determinate varieties will flower for a set period and ripen with earlier maturity of 80 to 90 days (Ács, 1980; Lazányi, 1999).

Field pea is very sensitive to heat stress at flowering, which can drastically reduce pod and seed set. There are two main types of dry pea (Duke, 1981; Bocz, 1992). One type has normal leaves and vine lengths of 80 to $120 \mathrm{~cm}$; the second type is the semi-leafless type, which has modified leaflets and shorter vine lengths. Pea normally has a single stem, but can branch from nodes below the first flower. Indeterminate varieties are more likely to compensate for dry weather and are more adapted to arid regions. Determinate, semi-leafless varieties have good standing ability and are more adapted to humid regions (Aykroyd and Doughty, 1972).

Dry pea seed will germinate at a soil temperature of $4{ }^{\circ} \mathrm{C}$. Emergence normally takes 10 to 14 days. Dry pea has hypogeal emergence in which the cotyledons remain below the soil surface. Pea roots can grow to a depth of 80 to $120 \mathrm{~cm}$; however, over $75 \%$ of the root biomass is within $40 \mathrm{~cm}$ of the soil surface. A relatively shallow root system and high water use efficiency make field pea an excellent rotational crop with cereals, especially in arid years, when soil moisture conservation is critical (Mándy et al., 1980; McKay et al., 1999). 


\section{RESULTS AND DISCUSSION}

Dry pea is adapted to different ecological conditions, grows on marginal land, plays an important role in crop rotation and provides an important source of vegetable protein. After beans and lentil, pea is the third most important legume produced for poorer consumers, particularly in developing countries, similar to chickpeas and cowpeas. Important production areas include France, Russia, Ukraine, Denmark and the United Kingdom in Europe; China and India in Asia; Canada and the USA in North America; Chile in South America; Ethiopia in Africa and Australia. World total dry pea production rose from 8-9 million tonnes in the 1970's to 16,7 million tonnes in 1990 (Figure 1).

Figure 1: World production and utilization of dry pea between 1961-1999

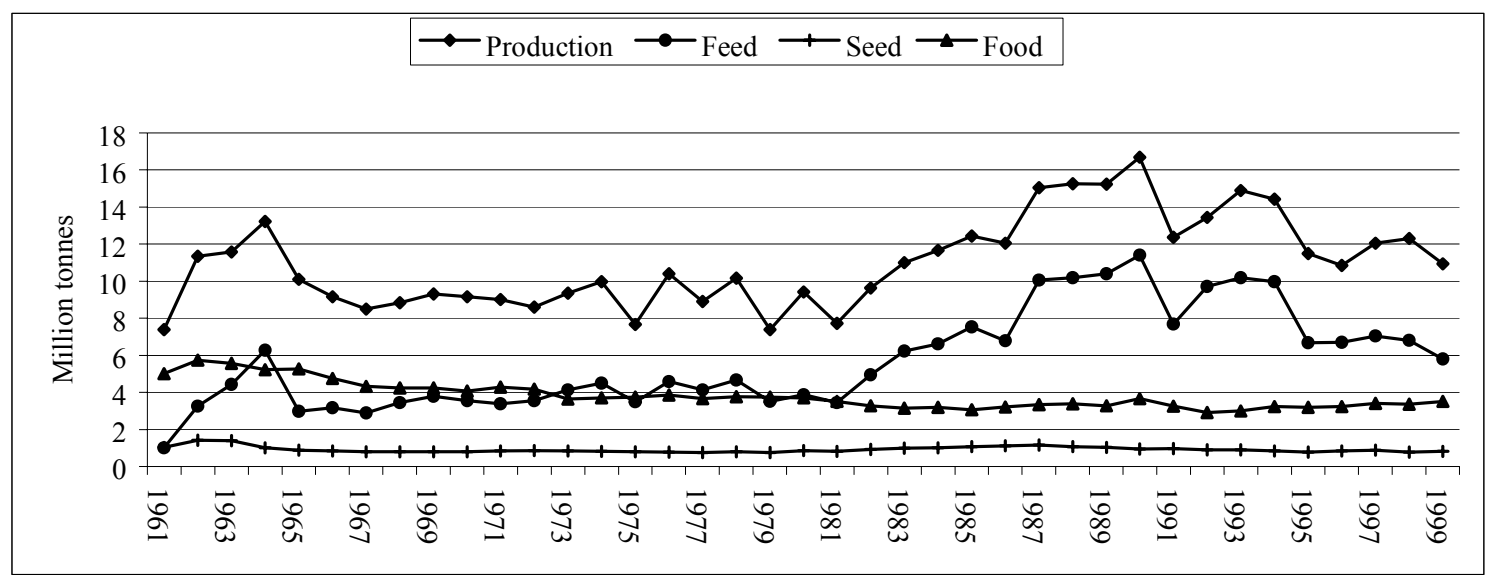

The increase in the production of dry pea does not reflect any rise in utilization for food by developing countries. At the beginning of the 1960's, the consumption of dry pea was $2,2 \mathrm{~kg} /$ capita, which reduced to $0,5 \mathrm{~kg} / \mathrm{capita}$ by the end of the 1990's. The level of human consumption of dry pea has decreased steadily, while growth occurred in feeding livestock. World production grew by $100 \%$ in the 1980 's, following a large increase in demand for feed by developed countries. In the middle of the 1990's, some $75 \%$ of world production was used as feed, 2-3 times higher than in the 1970's.

During the 1980's and the first half of the 1990's, dry pea production increased in the developed countries in both area and yield. Feed use also became increasingly important (Kralovánszky, 1975; Bódis, 1983). Environmental concerns also contributed to the increase in dry pea production. The trend in production has been maintained in Canada, Australia and many other countries, but, as a result of changes in CAP, dry pea production have been reduced in France. The new reforms in CAP include mandatory set-aside of arable land and a modified support system for grain legumes, which replaced the farmer minimum guaranteed prices applied with fixed area payments. A reduction in the support of area prices also reduced the demand for grain legumes as animal feed (Figure 2).

Figure 2: Dry pea production and utilization in the countries of the European Union

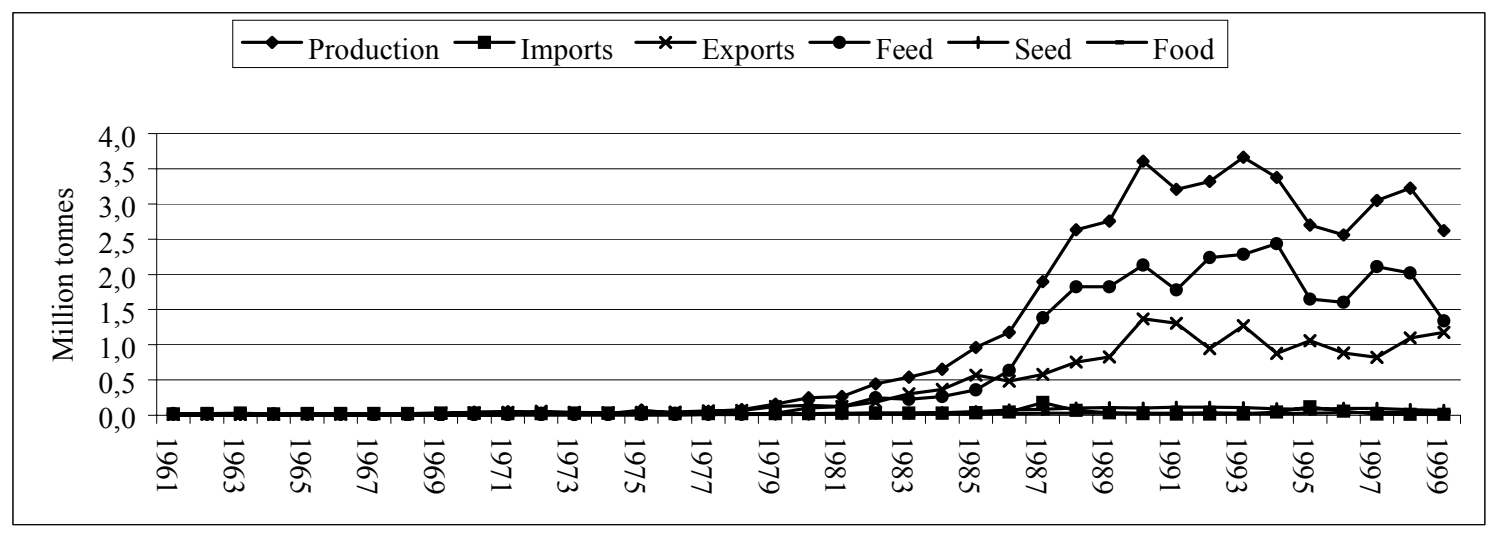

Production area varied from 7,763 hectares in 1994 to 5,872 million hectares in 2000. Dry pea production in Europe was 10,926 million tonnes in 1993, which was reduced to 5,727 million tonnes by 2000 (Table 1). The highest productivity for pea was reported in France, at $5512 \mathrm{~kg} / \mathrm{ha}$ in 1999, which is five times higher than the average yield in the Russian Federation (1094 kg/ha). Pea is the predominant export crop in world trade and represents about $40 \%$ of the total trade in grain legumes. The major exporting countries are France, Australia and Canada. 
Table 1: Trends in dry pea production (FAO Production Yearbook, 1000 tonnes)

\begin{tabular}{|c|c|c|c|c|c|c|c|c|}
\hline & 1992 & 1993 & 1994 & 1995 & 1996 & 1997 & 1998 & 1999 \\
\hline World & 13.431 & 14.899 & 14.423 & 11.494 & 10.841 & 12.044 & 12.309 & 10.945 \\
\hline Europe & 10.501 & 10.926 & 10.073 & 6.969 & 6.653 & 7.352 & 6.882 & 5.727 \\
\hline France & 3.318 & 3.664 & 3.378 & 2.701 & 2.562 & 3.052 & 3.225 & 2.622 \\
\hline Germany & 74 & 134 & 151 & 216 & 301 & 400 & 589 & 610 \\
\hline Russia & 2.607 & 2.526 & 2.287 & 1.212 & 1.323 & 1.196 & 660 & 598 \\
\hline Ukraine & 2.776 & 2.731 & 2.470 & 1.376 & 985 & 903 & 652 & 498 \\
\hline United Kingdom & 261 & 332 & 370 & 286 & 240 & 371 & 324 & 355 \\
\hline Denmark & 301 & 451 & 377 & 282 & 257 & 384 & 386 & 193 \\
\hline Belarus & 113 & 129 & 104 & 112 & 181 & 287 & 190 & 130 \\
\hline Hungary & 242 & 140 & 134 & 143 & 101 & 111 & 131 & 108 \\
\hline Czech Republic & & 206 & 149 & 130 & 120 & 93 & 122 & 105 \\
\hline Sweden & 10 & 10 & 10 & 28 & 68 & 114 & 88 & 85 \\
\hline Austria & 83 & 107 & 134 & 60 & 93 & 80 & 84 & 62 \\
\hline Slovakia & & 123 & 160 & 108 & 89 & 58 & 64 & 57 \\
\hline Poland & 60 & 64 & 53 & 57 & 66 & 55 & 63 & 55 \\
\hline Spain & 8 & 12 & 73 & 55 & 84 & 58 & 63 & 48 \\
\hline Lithuania & 14 & 18 & 20 & 4 & 19 & 19 & 73 & 47 \\
\hline Moldova & 104 & 93 & 52 & 40 & 16 & 35 & 47 & 34 \\
\hline Romania & 33 & 36 & 38 & 54 & 34 & 27 & 24 & 27 \\
\hline Italy & 35 & 29 & 23 & 20 & 12 & 10 & 11 & 22 \\
\hline
\end{tabular}

Dry pea was widely used as animal feed in the Soviet Union. Dry pea was grown on 7-8 million hectares in 1963 and 1964. There was a decrease in production area from the mid-1960's, which lasted until 1972. In the 1970's, dry pea was produced on 4 million hectares and there was an increase in the 1980 's, but it did not reach the means of the 1960's. The overall yield was 1,0 t/ha in the 1960's and 1,2 t/ha in the 1970's. Yield started to increase in the second part of the 1980's, and reached $2 \mathrm{t} / \mathrm{ha}$ in 1990. As a result of political changes, a strong reduction was recorded in the second half of the 1990's in the states of the former Soviet Union, where large quantities of dry pea was used for feeding livestock (Figure 3). Dry pea is expected to attract increased investment in these countries.

Figure 3: Dry pea production and utilization in the territory of the former Soviet Union

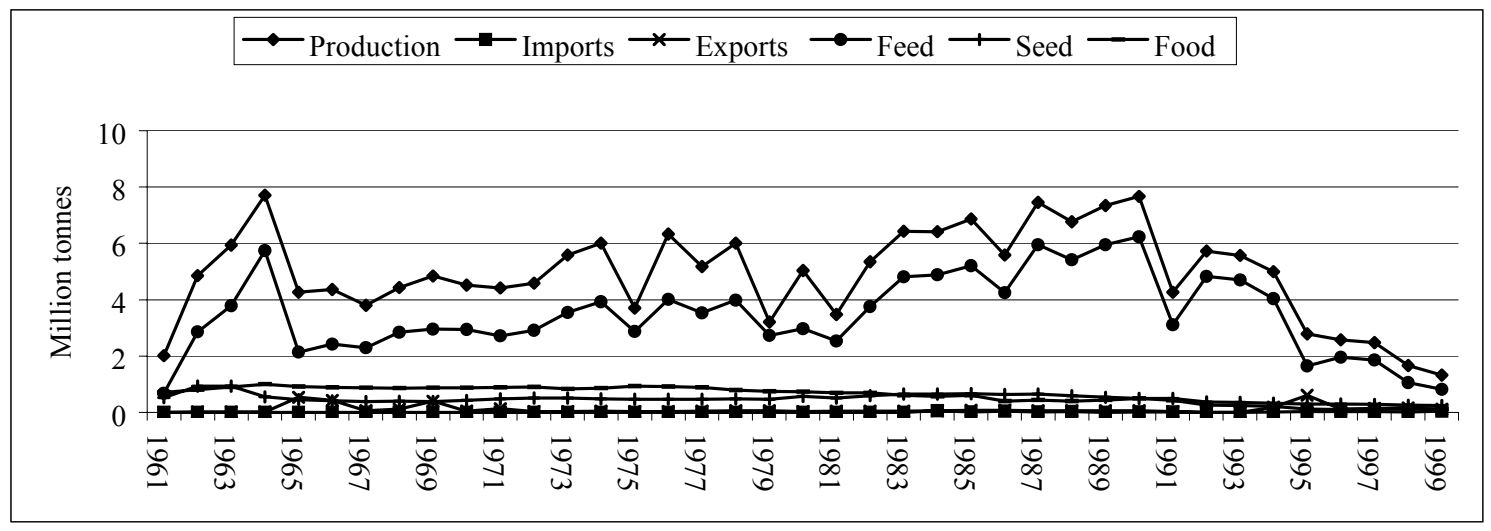

Dry pea production has also dropped in China. In contrast, in Australia and Canada dry pea production expanded due to improved export opportunities (Figure 4). Results indicate that Canada's share of the total export market is $40 \%$; making it the largest exporter of peas in the world (Table 2). Significant importing regions for Canadian peas are Western Europe and Asia. In Western Europe, where peas are destined mainly for livestock feed, the countries of Belgium, Spain and the Netherlands import the most, followed by Germany and Italy (Table 3). In Asia, where pea usage is mostly for human consumption, India is an increasingly significant importer. Approximately $35 \%$ of total Canadian pea production is used in Canada, especially for pig feed, with the remaining 65\% exported (Table 4). 


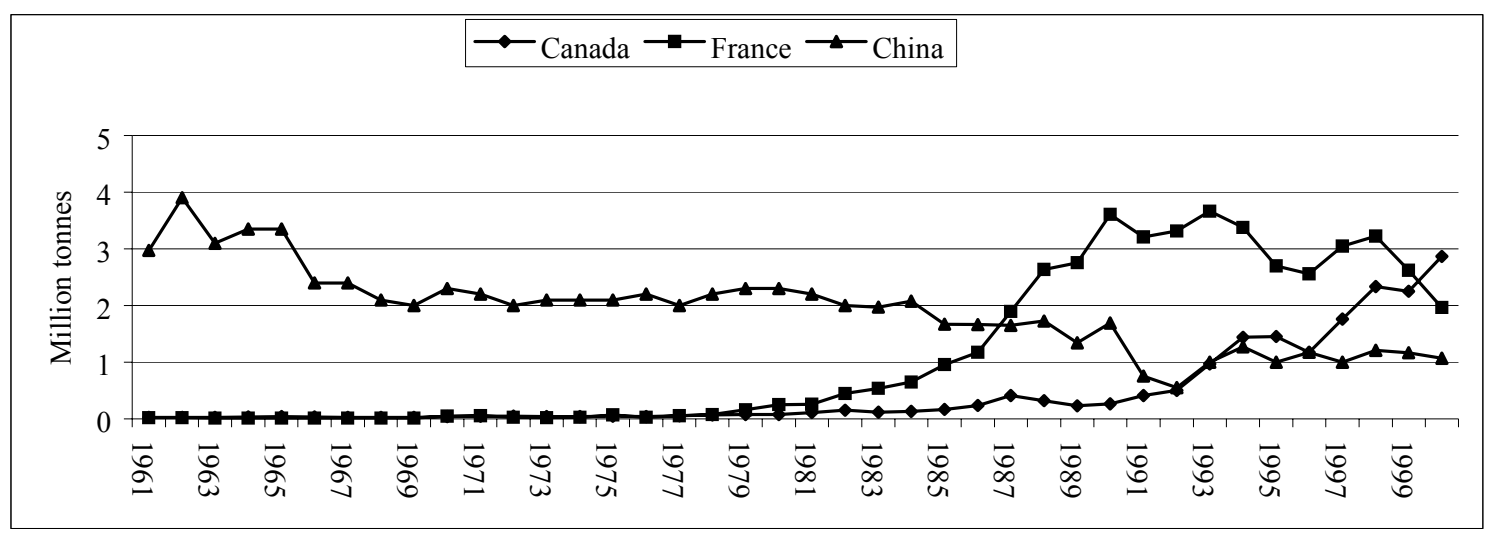

Table 2: Major dry pea exporting countries (FAO Production Yearbook, 1000 tonnes)

\begin{tabular}{|c|c|c|c|c|c|c|c|c|c|}
\hline & 1992 & 1993 & 1994 & 1995 & 1996 & 1997 & 1998 & 1999 & Mean \\
\hline France & 945 & 1,272 & 878 & 1,059 & 885 & 824 & 1.098 & 1.177 & 1.017 \\
\hline Canada & 298 & 504 & 686 & 1.054 & 856 & 873 & 1.138 & 1.437 & 856 \\
\hline Australia & 187 & 355 & 341 & 128 & 292 & 274 & 197 & 260 & 254 \\
\hline Ukraine & 1 & 5 & 120 & 462 & 97 & 132 & 145 & 91 & 132 \\
\hline Denmark & 126 & 201 & 178 & 64 & 46 & 131 & 80 & 86 & 114 \\
\hline USA & 96 & 103 & 122 & 112 & 117 & 100 & 127 & 101 & 110 \\
\hline Belgium* & 30 & 34 & 95 & 174 & 168 & 102 & 86 & 51 & 92 \\
\hline Czech Republic & & 112 & 153 & 108 & 72 & 68 & 30 & 75 & 88 \\
\hline Hungary & 196 & 90 & 64 & 54 & 26 & 16 & 20 & 22 & 61 \\
\hline United Kingdom & 116 & 47 & 55 & 48 & 40 & 54 & 52 & 31 & 55 \\
\hline Netherlands & 50 & 100 & 72 & 33 & 22 & 32 & 66 & 58 & 54 \\
\hline Slovakia & 0 & 38 & 69 & 61 & 44 & 24 & 24 & 31 & 42 \\
\hline
\end{tabular}

* Belgium+Luxembourg

Table 3: Major dry pea importing countries (FAO Production Yearbook, 1000 tonnes)

\begin{tabular}{|c|c|c|c|c|c|c|c|c|c|}
\hline & 1992 & 1993 & 1994 & 1995 & 1996 & 1997 & 1998 & 1999 & Mean \\
\hline Netherlands & 710 & 630 & 628 & 706 & 559 & 365 & 513 & 524 & 579 \\
\hline Belgium* & 390 & 410 & 485 & 642 & 636 & 513 & 579 & 569 & 528 \\
\hline Spain & 258 & 393 & 436 & 556 & 332 & 425 & 561 & 527 & 436 \\
\hline Germany & 556 & 507 & 468 & 425 & 223 & 141 & 131 & 164 & 327 \\
\hline India & 106 & 199 & 145 & 173 & 155 & 282 & 257 & 366 & 210 \\
\hline Italy & 32 & 23 & 31 & 193 & 89 & 86 & 99 & 108 & 82 \\
\hline China & 19 & 23 & 23 & 26 & 149 & 134 & 101 & 69 & 68 \\
\hline Colombia & 49 & 37 & 39 & 38 & 38 & 39 & 50 & 37 & 41 \\
\hline Bangladesh & 4 & 4 & 34 & 11 & 2 & 49 & 70 & 118 & 37 \\
\hline Pakistan & 6 & 5 & 17 & 89 & 88 & 3 & 30 & 44 & 35 \\
\hline USA & 19 & 24 & 24 & 37 & 34 & 39 & 35 & 31 & 31 \\
\hline Ireland & 42 & 28 & 25 & 20 & 22 & 55 & 14 & 20 & 28 \\
\hline Brazil & 18 & 21 & 28 & 24 & 27 & 27 & 26 & 30 & 25 \\
\hline Japan & 29 & 19 & 22 & 24 & 24 & 26 & 20 & 21 & 23 \\
\hline Peru & 10 & 14 & 22 & 17 & 21 & 25 & 43 & 28 & 22 \\
\hline
\end{tabular}

* Belgium+Luxembourg 
Table 4: Feeding dry pea in Europe (data from FAO Production Yearbook, 1000 tonnes)

\begin{tabular}{|c|c|c|c|c|c|c|c|c|c|}
\hline & 1992 & 1993 & 1994 & 1995 & 1996 & 1997 & 1998 & 1999 & Mean \\
\hline World & 9.720 & 10.193 & 9.973 & 6.683 & 6.693 & 7.052 & 6.805 & 5.806 & 7.866 \\
\hline Canada & 122 & 472 & 550 & 374 & 305 & 450 & 493 & 510 & 410 \\
\hline Europe & 9.325 & 9.317 & 8.916 & 6.018 & 5.842 & 5.998 & 5.614 & 4.646 & 6.960 \\
\hline France & 2.241 & 2.282 & 2.433 & 1.649 & 1.604 & 2.109 & 2.022 & 1.339 & 1.960 \\
\hline Ukraine & 2.296 & 2.257 & 1.908 & 652 & 661 & 554 & 295 & 215 & 1.105 \\
\hline Russian Federation & 2.272 & 2.201 & 1.930 & 850 & 1.081 & 965 & 452 & 418 & 1.271 \\
\hline Germany & 553 & 555 & 535 & 518 & 391 & 357 & 524 & 547 & 498 \\
\hline Netherlands & 654 & 516 & 538 & 650 & 516 & 309 & 421 & 442 & 506 \\
\hline Belgium* & 361 & 390 & 391 & 462 & 461 & 407 & 488 & 514 & 434 \\
\hline Spain & 247 & 380 & 478 & 575 & 390 & 455 & 588 & 541 & 457 \\
\hline Denmark & 149 & 195 & 241 & 182 & 167 & 195 & 225 & 180 & 192 \\
\hline Belarus & 100 & 115 & 91 & 95 & 152 & 255 & 169 & 114 & 136 \\
\hline Sweden & 4 & 4 & 5 & 18 & 56 & 92 & 66 & 71 & 40 \\
\hline Austria & 73 & 95 & 122 & 58 & 92 & 71 & 73 & 44 & 79 \\
\hline Moldova & 89 & 79 & 43 & 33 & 11 & 31 & 40 & 15 & 43 \\
\hline Slovakia & & 66 & 55 & 39 & 22 & 17 & 19 & 17 & 34 \\
\hline Czech Republic & & 46 & 13 & 6 & 34 & 9 & 36 & 23 & 24 \\
\hline Hungary & 56 & 31 & 27 & 36 & 25 & 39 & 49 & 30 & 37 \\
\hline Romania & 26 & 29 & 29 & 43 & 18 & 9 & 12 & 12 & 22 \\
\hline Ireland & 35 & 22 & 20 & 15 & 17 & 50 & 10 & 16 & 23 \\
\hline
\end{tabular}

* Belgium+Luxembourg

During the last decade, Canadian pea production increased by $450 \%$, with most of the increase attributable to expanded seeded acreage. Because of this surge in production, Canada is expected to become the world's largest producer of dry peas in $2000-2001$, with a $23 \%$ share of world production. France is forecasted to be a close second, with $21 \%$ of total production. In Canada and Australia, exports are likely to grow more slowly than in the past, partly because of weaker import demand for feed. Feed demand in developing countries will continue to grow at a considerably faster rate than in developed countries. However, the gap between the two groups of countries will remain wide. Compared with the development in the 1980's, the growth in feed demand is projected to be significantly slower in both groups of countries. Hungary produced 0,4 million tonnes dry pea in 1989 , and about 0,1 million tonnes since 1995. Export was highest in 1991 and lowest in 1999 (Figure 5).

Figure 5: Dry pea production and utilization in Hungary

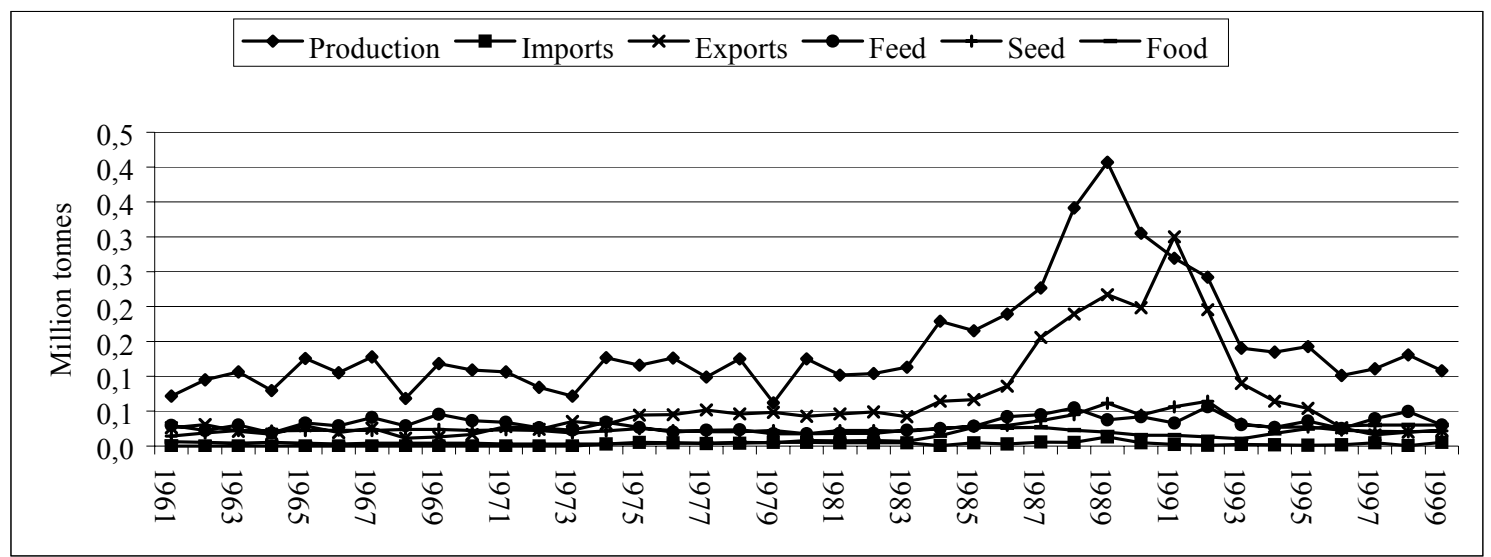

Word demand for dry pea for feed increased from 4 million tonnes in the 1970's to 10 million tonnes by the end of 1980's. In the coming decades, world dry pea production and utilization as feed are expected to expand at a lower rate than in the 1980's. Most of this increase is expected to occur in Eastern European countries, Canada and Australia, where production is anticipated to grow at $2 \%$ annually. 
Europe, which accounts for $80-90 \%$ of world total feed use, is likely to recover and expected to grow. In the countries of the former Soviet Union, feed utilization is also expected to grow, but until 2010, it does not reach the production level of the 1980's. In aggregate, the Eastern European countries are likely to improve their production in the new millennium. Export from Eastern Europe will also expand, with a possible increase in the market share of the EU. Research will be focused on new production technologies, more productive varieties, and on breeding for drought and disease resistance. An improved extension service and capital investments will help this process (Iszályné, 2002; Lazányi, 2002).

The impact of yield increase will also be strong in North America and in Far Eastern countries. The rise in yield and production in these countries will result in research into new production technologies and more productive varieties, and improved extension services. Research will be focused on the development of high yielding, short duration varieties and on breeding for drought and disease resistance.

\section{REFERENCES}

Ács, A. (1980): A borsó termesztése. Mezőgazdasági Kiadó, Budapest

Aykroyd, W.-Doughty, R. (1982): Legumes in Human Nutrition. FAO, Rome

Bocz, E. (1992): Szántóföldi Növénytermesztés. Mezőgazda Kiadó, Budapest

Bódis, L. (1983): Az abrak hüvelyesek termesztése. Mezőgazdasági Kiadó, Budapest

Duke, J. A. (1981): Hand book of legumes of world economic importance. Plenum Press, New York, 199-265.

Iszályné, T. J. (2002): Néhány gondolat a szárazborsó termesztéséről, nemesítéséről. Gyakorlati Agrofórum, 13. 2. 27-29.

Iszályné, T. J.-Lazányi, J. (1993): Szárazborsó. Lazányi, J. (ed.) A Debreceni Agrártudományi Egyetem kutatóhelyein nemesített és fenntartott növényfajták ismertetése. Debrecen, 120-129.

Kralovánszky, U. P. (1975): A fehérje probléma. Mezőgazdasági Kiadó, Budapest

Kurnik, E. (1970): Étkezési és abraktakarmány-hüvelyesek termesztése. Akadémia Kiadó, Budapest

Lazányi, J. (1999): Protein peas (Pisum sativum L.). In: Lazányi, J.-Dobránszki, J. (ed.) Agricultural Research in Nyírség Region. Nyíregyháza, 36-44.

Lazányi, J. (2002): A szárazborsó-termesztés tendenciái. Gyakorlati Agrofórum, 13. 2. 25-26.

Lazányi, J. (ed.) (1998): Use of alternative crops for forage production and soil conservation. Papers presented within the programme of Co-operation in Science and Technology between the Governments of the Republic of Hungary and Japan. Nyíregyháza, 1-162.

Mándy, Gy.-Szabó, L.-Ács, A. (1980): A borsó. Magyarország kulturflórája. Akadémiai Kiadó, Budapest

McKay, K.-Schatz, B.-Endres, G. (1999): Field Pea Production. North Dakota State University NDSU. Extension Service

Yacentiuk, M. (2001): Canadian Feed Pea Production and Usage. Livestock. Manitoba Agriculture and Food

FAO Production Yearbook (1961-2000): FAO, Rome 